African Crop Science Journal by African Crop Science Society is licensed under a Creative Commons Attribution 3.0 Uganda License. Based on a work at www.ajol.info/ and www.bioline.org.br/cs DOI: http://dx.doi.org/10.4314/acsj.v24i3.5

\title{
HARDPAN AND MAIZE ROOT DISTRIBUTION UNDER CONSERVATION AND CONVENTIONAL TILLAGE IN AGRO-ECOLOGICAL ZONE IIA, ZAMBIA
}

\author{
K.B. ESSER \\ Norwegian University of Life Sciences, Department of Environmental Sciences, P. O. Box 5003, \\ 1430 Aas, Norway \\ Corresponding author: kjell.esser@nmbu.no
}

(Received 28 June, 2016; accepted 23 August, 2016)

\begin{abstract}
Hardpans (plough/hoe pans) are commonly believed to restrict plant root growth and crop yields under conventional small-scale agriculture in sub-Saharan Africa. This study questions the notion of widespread hardpans in Zambia and their remedy under conservation tillage. Soil penetration resistance was measured in $8 \times 12$ grids, covering 80 $\mathrm{cm}$ wide and $60 \mathrm{~cm}$ deep profiles in 32 soil pits. Large and fine maize roots were counted in $8 \times 6$ grids. Soil samples from mid-rows were analysed for $\mathrm{pH}$, exchangeable $\mathrm{H}^{+}$, exchangeable $\mathrm{Al}^{3+}$, cation exchange capacity, total $\mathrm{N}$ and extractable P (Bray 1) at six depths from 0-10 to 50-60 cm. Cultivation-induced hardpans were not detected. Soils under conservation tillage were more compact at $5 \mathrm{~cm}$ depth than soils under conventional tillage. No differences in root distributions between conservation and conventional tillage were found. Maize (Zea mays L.) roots were largely confined to a relatively small soil volume of about $30 \mathrm{~cm}$ x $30 \mathrm{~cm}$ x $30 \mathrm{~cm}$. Root growth appeared to be restricted by a combination of low concentrations of $\mathrm{N}$ and P. Soil acidity and $\mathrm{Al}$ saturation appeared to play a minor role in root distribution. L-shaped taproots in soils under manual tillage reported earlier were not necessarily due to hardpans, but may rather be caused by temporarily dry, impenetrable subsoils early in the rain season. There is no scientific basis for the recommendation given to farmers by agricultural extension workers to " $b r e a k$ the hardpan" in fields under manual or animal tillage in the study areas.
\end{abstract}

Key Words: Soil acidity, Zea mays

\section{RÉSUMÉ}

Pans de charrue sont communément admis pour limiter la croissance des racines des plantes et les rendements des cultures dans l'agriculture à petite échelle conventionnelle en Afrique sub-saharienne. Cette étude remet en question la notion des pans de charrue répandues en Zambie et leur remède en vertu de labour de conservation. Résistance à la pénétration du sol a été mesurée dans 32 trous de sol en $8 \times 12$ grilles couvrant $80 \mathrm{~cm}$ de largeur et $60 \mathrm{~cm}$ de profondeur. Grosses et fines racines de maïs ont été comptés dans grilles de $8 \times 6$. Des échantillons de sol au milieu des rangs ont été analysés pour le $\mathrm{pH}$, le $\mathrm{H}^{+}$échangeable, le $\mathrm{Al}^{3+}$ échangeable, la capacité d'échange de cations, et le total $\mathrm{N}$ et $\mathrm{P}$ extractible (Bray 1) à six profondeurs de 0-10 à 50-60 cm. Pans de charrue induites par la culture ne sont pas détectés. Les sols sous labour de conservation étaient plus compacts à $5 \mathrm{~cm}$ de profondeur que les sols sous labour conventionnel. Aucun différence dans la répartition des racines entre lelabour durable et le labour conventionnel n'ont été trouvés. Racines de maïs ont été largement confinées à un volume relativement faible d'environ $30 \mathrm{~cm}$ x $30 \mathrm{~cm}$ x $30 \mathrm{~cm}$ de sol. La croissance des racines semble être limitée par une combinaison de faibles concentrations d'azote et de phosphore à l'extérieur des volumes de sols affectés par l'application d'engrais. L'acidité du sol et la saturation d'aluminium semblait jouer un rôle mineur pour la distribution des racines. Observations des racine pivotante en forme de $\mathrm{L}$ dans les sols sous labour manuel 
rapportés plus tôt ne sont pas nécessairement en raison de pans de charrue, mais peuvent plutôt être causés par des sous-sols impénétrables qui sont temporairement sèches au début de la saison des pluies. Il n'y a aucune base scientifique pour la recommandation donnée aux agriculteurs par les organismes de développement à «briser la pan de charrue" dans les champs sous labour manuel ou animale dans les zones d'étude.

Mots Clés: Sacidité du sol, Zea mays

\section{INTRODUCTION}

Negative effects of hardpans (plough pans and hoe pans) on crop yield under conventional oxplough and hand-hoe cultivation are commonly referred to by agricultural project documents and extension manuals for sub-Saharan Africa. Such pans are regarded as significant obstacles to root development and water infiltration to the subsoil, resulting in constrained crop yield (Baudron $e t$ al., 2007; ICRAF, 2009; FAO, 2009; SUSTAINET EA, 2010; IFAD, 2011). As such, reduced soil tillage in the form of relatively deep planting basins or rip lines are widely recommended to break hardpans and to avoid further pan formation (CFU, undated; Otieno, 2012).

The scientific evidence of hardpans in African non-mechanised agriculture is, however, limited. The presence of hardpans is sometimes deduced from abnormal shapes of plant roots (L-shaped taproots). For instance, Douglas et al. (1999) concluded on the basis of shapes and distributions of crop roots in Malawi that cultivation-induced hoe pans reduce crop yields significantly. Although the presented data for soil bulk density did not indicate compacted hardpans in the studied soils, the authors concluded that "changes recorded between the topsoil and upper subsoil can in most cases be attributed to cultivation induced compaction". Similarly, Baudron et al. (2007) stated that "taproot bent within $20 \mathrm{~cm}$ of soil depth is evidence of plough pan".

Based on penetration resistance measurements, Materechera and Mloza-Banda (1997) concluded that " $a$ strong and compact layer had developed beneath the ridges in both [conventional and minimum tillage] treatments" in Malawi. However, soil strength increased gradually from about $0.25 \mathrm{MPa}$ at $5 \mathrm{~cm}$ soil depth, to a maximum level of 2.0 to $2.2 \mathrm{MPa}$ at $40-50 \mathrm{~cm}$ depth. Penetration resistance maxima at 40 to 50 $\mathrm{cm}$ soil depths were subsequently presented as indications of cultivation-induced hardpans by Wall et al. (2014). With reference to Materechera and Mloza-Banda (1997), Wall et al. (2014) stated that "severe hard pans are common in manually cultivated farms in Malawi and Mozambique". However, observed compact layers at 40 to $50 \mathrm{~cm}$ depth are well known to be natural, illuvial clayenriched soil horizons in Luvisols, Lixisols and Acrisols, which are commonly found in subSaharan Africa (cf. FAO, 2006; Avornyo et al., 2013). Such clay-enriched layers are not caused by cultivation.

Materechera and Mloza-Banda (1997) observed elevated penetration resistance in the topsoil under minimum tillage compared to conventional hoe tillage. Correspondingly, root length density (RLD; cf. Chopart and Siband, 1999) was lower under minimum tillage compared to conventional hoe tillage. Root length density reached maximum values (in terms of $\mathrm{m} \mathrm{m}^{-3}$ ) at shallower depths under minimum tillage $(18 \mathrm{~cm})$, compared to hoe tillage $(25 \mathrm{~cm})$ apparently due to differences in soil density.

Haggblade and Tembo (2003) stated that Zambia's Agro-ecological Region I and IIa have "extensive plow-pan damage", but did not provide scientific evidence of hardpans. Mazvimavi et al. (2008) presented data for soil bulk density in 37 soils in Zimbabwe, without evidence of compacted layers under either conservation or conventional tillage. Bulk density increased gradually from the soil surface down to $30-35 \mathrm{~cm}$ depth. Not surprisingly, bulk density was lower within newly dug planting basins, with organic matter added, compared to the top $15 \mathrm{~cm}$ between basins and compared to conventionally tilled fields.

Older soil survey literature from Zambia alludes occasionally to the problem of hardpans and relates them to the use of farm machinery (Brammer, 1973; Tiller, 1975). While surveying Kalichero soils in the Chipata area, Brammer (1973) noted that "Under good management ... and 
avoidance of cultivation by machinery when the soils are wet, [it] should be possible to maintain good structure in the topsoil'. The author did not mention hardpan formation due to crop cultivation in the presentation of soils in the Southern Province of Zambia. Tiller (1975) observed that a compact and hard soil layer commonly occurred at $30 \mathrm{~cm}$ depth in abandoned slash-and-burn (chitemene) gardens on Sandveldt soils in the Central Province. The author inferred that the hard layer was a "plough pan developed during previous cultivation" presumably as a result of earlier mechanised cultivation by immigrant settlers.

In a review of causes, effects and control of soil compaction in South Africa, Bennie and Krynauw (1985) referred to "vehicular traffic" as the principal external cause of soil compaction. Cattle and human trampling may also cause significant soil compaction, but the effect is largely restricted to the top 5 to $10 \mathrm{~cm}$ of soils (Mulholland and Fullen, 1991; Usman ,1994).

During the last decade, extension agencies in Zambia recommended small-scale farmers to "break the hardpan" by soil ripping and digging of planting basins as part of conversion to conservation agriculture. The relatively heavy chaka hoe is recommended to break plough pans (CFU, 2011). Farmers who follow the advice, till deeper and at a higher labour cost than they otherwise would require.

The objective of this study was to clarify the need for "breaking the hardpan" in the Agroecological Zone IIa, Zambia by (1) detecting the presence or absence of hardpans (plough pans); (2) determining whether or not conservation tillage, i.e., the use of planting basins and rip lines, leads to deeper root development of maize plants as a result of "breaking the hardpan" compared to conventional tillage by ox-plough and handhoe ridging (which will reinforce hardpans according to common narratives); and (3) indicating whether or not maize root distributions might be more constrained by chemical than physical soil properties. This investigation was part of a larger, four-year study on the effects of conservation agriculture on soil fertility, agroeconomy and socio-economy among selected small-scale farmers in Zambia.

\section{MATERIALS AND METHODS}

Study areas. Fifteen small-scale farmers practising both conservation and conventional tillage in each of the Central, Southern and Eastern provinces of Zambia, and located within the Agro-Ecological Zone IIa, were selected for the study (Fig. 1). Agro-Ecological Zone IIa is

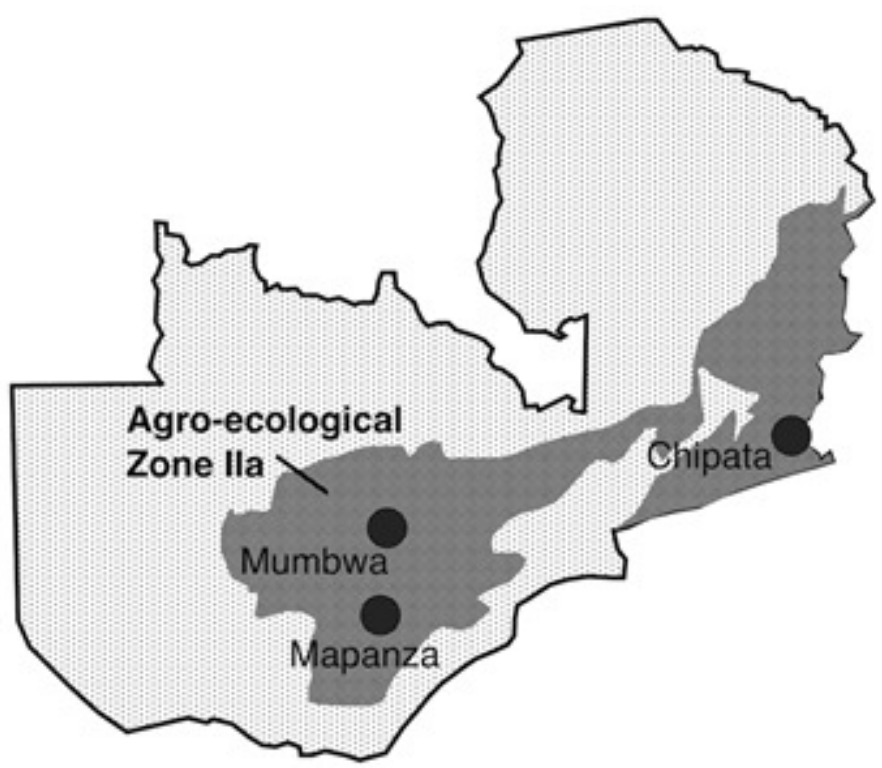

Figure 1. Map of Zambia with Agro-ecological Zone lla and approximate locations of the Mumbwa, Mapanza and Chipata study areas. 
characterised by an annual rainfall of 800-1000 $\mathrm{mm}$, moderately leached sandy loams, and a growing season of 100-140 days. The cropping potential is classified as 'good', i.e., the best of Zambia's three agroecological zones (Chikowo, undated).

Farmers were selected on the basis of length of conservation farming (minimum 5-10 years) and commitment to the principles of conservation agriculture (preferably farmer who were trained to train other farmers, known as "farmer coordinators" or "lead farmers"). Farms were selected within a radius of about $50 \mathrm{~km}$ from Mumbwa (Central Province), Mapanza (Southern Province) and Chipata (Eastern Province). Average annual precipitation for Mumbwa is 900 $\mathrm{mm}$, Mapanza (Choma) about $800 \mathrm{~mm}$, and Chipata $1000 \mathrm{~mm}$ (Climatemps.com, undated).

Soils and crops. Soils in the agro-ecological zone IIa are generally classified as Ferric/Orthic Acrisol (acid soils with subsoil accumulation of lowactivity clay, developed in acid rocks) and Ferric Luvisol (less acid soils with subsoil accumulation of high-activity clay, developed in basic rocks). There are some occurrences of Chromic Luvisol and Eutric Nitisol (deep, well-drained red soils with relatively high base saturation) (FAOUNESCO, undated).

Soils in the Mumbwa area appear to be more commonly of residual origin, containing more clay than in the Mapanza area, where soils in large areas have formed in sandy river deposits. In the Chipata area, soils appear to be largely of residual origin, but younger and less leached compared to soils in the Mumbwa area due to a more hilly topography in the Chipata area.

A total of 16 pairs of conservation and conventionally tilled soils, planted with maize (Zea mays L.) were included in the study (a total of 32 soil pits). Seven pairs were analysed in the Mumbwa area, 7 in the Mapanza area and 3 in the Chipata area. More pits were dug near Chipata, but their data were discarded due to significant variations within pairs in terms of soil parent material.

Root counts in four soil pits were discarded due to unsatisfactory data quality. Pairs of soil pits under conservation and conventional tillage were selected as close to each other as possible
(10-50 $\mathrm{m}$ apart) on each farm, to minimise natural variations in soil and rainfall conditions within pairs. Similarity in soil characteristics within pairs of conservation and conventional fields was given priority over similarity in maize genotype in the selection of study sites.

Prior to the current tillage regimes, both conservation and conventionally tilled fields had been conventionally cultivated for 30-40 years using plough or hand hoe. The current conservation fields had been tilled only by oxdrawn ripping (12-15 $\mathrm{cm}$ deep furrows) or handdug planting basins (approx. $15 \mathrm{~cm}$ wide, $30 \mathrm{~cm}$ long and $15 \mathrm{~cm}$ deep) for the last 5-10 years. Rip lines and planting basins had been reopened every season, leaving the soil in-between untilled. Tillage of conventional fields had remained unchanged. If plough pans (hardpans) had formed during the time of conventional tillage, ripping and digging of basins during the last 510 years would "break the hardpan" only within the rip lines and basins. Between rip lines and basins, we can expect to find plough pans formed during the previous conventional tillage, although biological activity might have reduced the solidity of such pans during the recent years of no tillage.

Some of the conservation-tilled fields had occationally been weeded by ox-drawn cultivators or hand hoes to form ridges along the maize rows. However, weeding by cultivator is generally too shallow to affect potential plough pans. For both conservation and conventional fields, farmers placed fertiliser by hand around the seeds or seedlings for basal dressing (Compound D) and around individual plants for top dressing (urea). Under conventional tillage, most farmers covered the applied urea by a soil ridge along the plant row. Broadcasting of fertiliser was not practiced.

In each field, a $1 \mathrm{~m} \times 1 \mathrm{~m} \times 1 \mathrm{~m}$ soil pit was dug at the end of the cropping season (April) when the soil was relatively dry and maize roots were still intact. The pits were positioned such that one representative maize plant was located in the middle of a soil profile. Thus, with a planting distance of about $80-90 \mathrm{~cm}$, the soil profiles represented a cross-section of one crop row and two half mid-rows on either side. Plants with roots attacked by termites, were not includded in the study. All maize plants selected for root counts 
were stand-alone plants uninfluenced by neighbouring plants. The fields contained different maize varieties including hybrids, recycled hybrids and local varieties.

Soil penetration resistance. Penetrometer measurement is a reliable proxy for the pressure required by roots to penetrate soils during root elongation (Taylor and Ratliff, 1969; Whiteley $e t$ al., 1981; Bengough and Mullins, 1991). Previous studies of hardpans in the region were largely based on bulk density measurements, which is labour intensive and costly. Thus, the studies relied on relatively few samples, leading to the possibility of not detecting relatively thin plough pans. Bulk density may also correlate less well with root development (Lampurlanés and Cantero-Martínez, 2003). In the present study, 96 soil penetrometer readings were taken in $5 \mathrm{~cm} \mathrm{x}$ $10 \mathrm{~cm}$ rectangles for each soil profile, i.e., eight by twelve readings, horizontally and vertically, respectively, using a Durham S-170 penetrometer. Thus, use of a penetrometer facilitated collection of a much more detailed dataset for each soil profile than would be obtained through bulk density measurements. Since the firmness of soil depends on soil moisture, the $80 \mathrm{~cm} \times 60 \mathrm{~cm}$ profiles were wetted with $2.5 \mathrm{~L}$ of water, by moving a mist sprayer repeatedly horizontally and vertically, to ensure homogenous wetting. After absorption of $2.5 \mathrm{~L}$ of water, soil moisture in a 1 $\mathrm{cm}$ thick vertical layer of the profile was apparently at or close to field capacity, with a horizontally decreasing moisture to dryness at 3-4 cm. Since the penetrometer moves only $0.5 \mathrm{~cm}$ deep, readings were made in soil that was near field capacity. Measurement of abnormally hard and soft spots in the soils, such as weathered rocks, concretions, large root canals and termite nests were avoided. Penetrometer readings in all provinces were measured by the same person to ensure consistent readings.

In addition to penetrometer readings, the firmness of soil profiles were tested subjectively for possible compacted layers that might have escaped penetrometer measurements. This was done by gently excavating a vertical groove in the soil profile with a trowel. Variations in capillary conductivity were also observed subjectively, by carefully scraping off the soft, moist soil from the profile, after penetrometer readings had been done, and observing the microrelief of dry soil that emerged. Information from the hand tests of soil firmness and capillary conductivity were not recorded quantitatively, but observed as a subjective supplement to the penetration measurements with focus on detecting signs of cultivation induced hardpans. Since the data were analysed pairwise for similar soils, effects of variations in soil texture were eliminated. Hence, soil texture is not reported in this paper.

Root distribution. Visible roots in the soil profile were counted in each of forty-eight $10 \mathrm{~cm}$ x $10 \mathrm{~cm}$ squares, i.e., eight squares horizontally by six squares vertically. The method of root counting, as opposed to more advanced methods, was chosen because of its simplicity and speed of operation. More advanced methods of root studies can be "tedious and time consuming" and may require advanced field equipment (Taylor et al., 1991). Within each province, the same person counted the roots in all soil profiles to secure consistent counting for pair-wise comparison.

First order seminal and nodular roots were counted as "large roots", while secondary roots $<2 \mathrm{~mm}$ in diameter were counted separately as "fine roots".

Farmers had planted both hybrid maize with a relatively profuse root system; as well as local maize varieties with a more modest root system, in the studied fields. Some farmers preferred to plant hybrid maize in conservation fields and local varieties in ploughed or hoed fields. A few farmers held the opinion that hybrid maize performs poorly under conservation tillage. A direct comparison of root counts under conservation tillage and conventional tillage, would, therefore, be influenced by systematic differences in the use of hybrid and local maize varieties. To reduce the effect of plant varieties, root distributions are expressed as ratios between the number of roots in the $8 \times 6$ soil squares to the average number in the two top $10 \mathrm{~cm} \times 10 \mathrm{~cm}$ squares on each side of the base of the maize plants (Fig. 2). For the purpose of this paper, this ratio is referred to as the "root distribution index". The index expresses the extent to which roots extended 


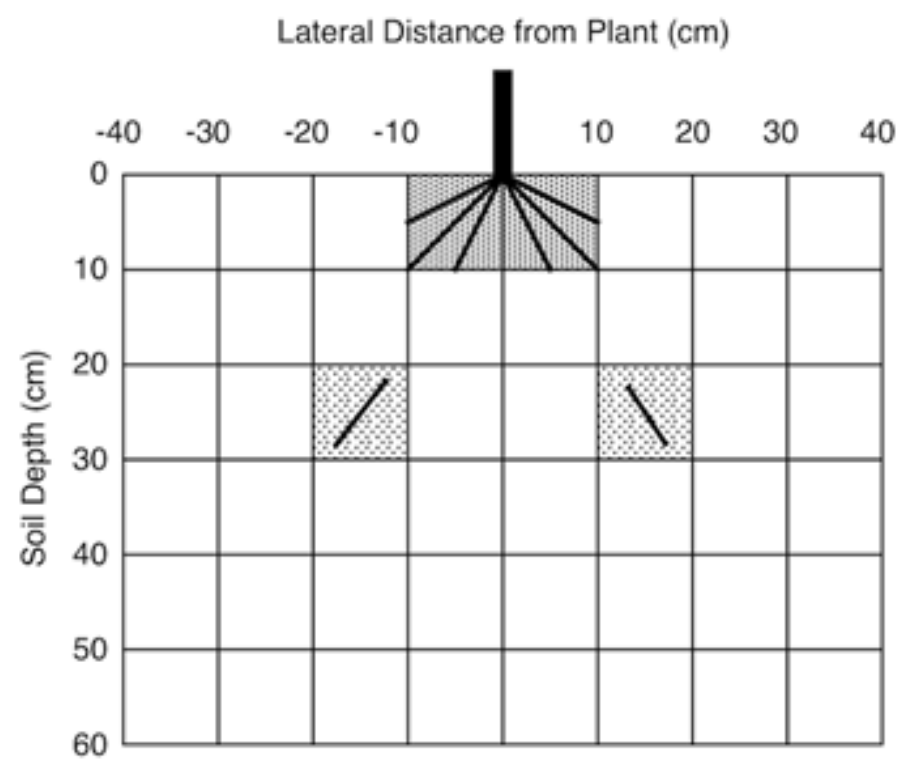

Figure 2. Soil squares used to count roots and example of squares used to calculate root distribution index. In this case, the two squares at -10 to $-20 \mathrm{~cm}$ and +10 to $+20 \mathrm{~cm}$ lateral distance from the plant, both at $20-30 \mathrm{~cm}$ depth, are compared to the average at $0- \pm 10 \mathrm{~cm}$ lateral distance and $0-10 \mathrm{~cm}$ depth. The index for this schematic example is $1 / 3$.

laterally and vertically into a larger soil volume, or in other words, to what extent the roots were restricted to a small volume near the plant base.

The root distribution indices were used to compare root data for conservation tillage and conventional tillage. To facilitate a standardised comparison, ratios of root distribution indices between conservation and conventionally tilled fields were calculated. Ratios of root distribution indices for conservation and conventional tillage above 1 for a particular square in the soil profiles, indicate greater root growth from the plant to the square in question under conservation tillage compared to conventional tillage. Conversely, ratios below 1 suggest greater root growth under conventional tillage compared to conservation tillage. If we assume a restricting hardpan under conventional tillage, and easier growth or passage of roots through broken hardpans under conservation tillage, we can expect ratios below 1 in the surface squares $(0-10 \mathrm{~cm}$ soil depth) since roots under conventional tillage would tend to grow more horizontally above hardpans. Under such conditions, data points would concentrate within the solid oval depicted in Figure 3. In the presence of hardpans, we would also expect ratios above 1 in squares below hardpans due to easier downward growth under conservation tillage. If so, data points would be likely to fall within the dashed ovals (Fig. 3).

Soil chemical analysis. Six soil samples were taken from the mid-rows (i.e., about $40 \mathrm{~cm}$ laterally from the plant rows) of each profile at 0-10, 10-20, 20-30, 30-40, 40-50 and 50-60 cm soil depths. They were analysed for $\mathrm{pH}-\mathrm{CaCl}_{2}$, exchangeable $\mathrm{H}^{+}$and $\mathrm{Al}^{3+}(1 \mathrm{M} \mathrm{KCl})$, cation exchange capacity (1M $\mathrm{NH}_{4} \mathrm{OAc}$ at $\mathrm{pH}$ 7), total nitrogen (Macro-Kjeldahl) and extractable phosphorus (Bray-1) according to UNZA (1998). Mid-row samples were selected to reduce impacts of variable lime and fertiliser applications.

Statistical analysis. Data were tested statistically using pairwise Student's $t$-tests, with confidence level $\mathrm{P}<0.05$, using Microsoft Excel. Despite negative statistical tests in some cases, data are shown graphically partly to document absence of significant differences and to indicate possible non-significant trends that might be of interest for further studies. 


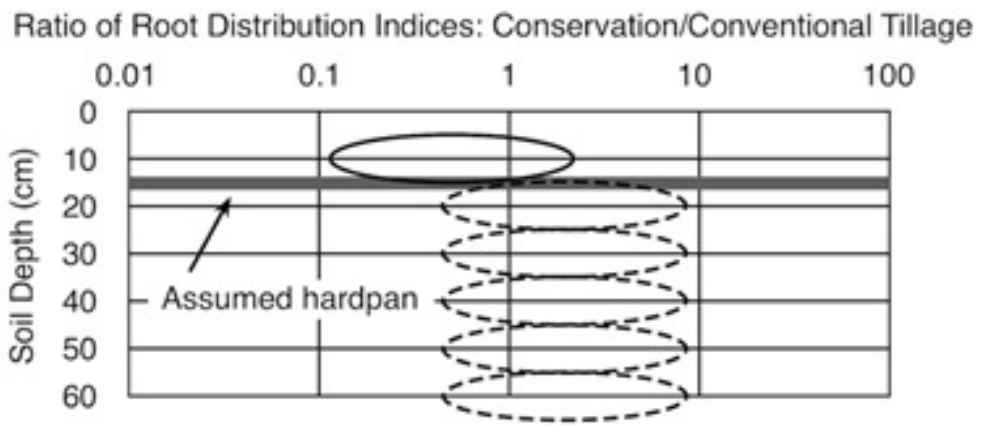

Figure 3. Expected clusters of data points for conservation/conventional ratios of root distribution indices if roots under conservation tillage are less restricted by hardpans compared to those under conventional tillage.

\section{RESULTS}

Soil penetration resistance. Average penetrometer readings for all soil depths were $0.16 \pm 0.06 \mathrm{MPa}$. The lowest average penetration resistance for one soil depth in one soil profile was $0.03 \mathrm{MPa}$ and the highest was $0.38 \mathrm{MPa}$. Only three soil "horizons" had resistance above $0.30 \mathrm{MPa}$, all of which were at the 45 to $60 \mathrm{~cm}$ depth. Average readings for each of the three study areas - and for all areas combined - are presented in Figure 4.

Pairwise penetration resistance ratios between conservation and conventional tillage were not statistically different from 1.0 at soil depths 10 to $60 \mathrm{~cm}$ (Fig. 5). At $5 \mathrm{~cm}$ soil depth, however, soils under conservation tillage were more compact than those under conventional tillage by a mean factor of $1.70(\mathrm{P}<0.026)$.

The data suggest a systematic difference in the horizontal pattern of values for penetration resistance between conservation and conventional tillage (Fig. 6). At $5 \mathrm{~cm}$ soil depth, there was a significantly higher penetration resistance in the middle of the plant rows, i.e., at $\pm 40 \mathrm{~cm}$ from the plants, under conservation tillage compared to conventional tillage $(\mathrm{P}<0.04)$. Differences in resistance between conservation and conventional tillage closer to the plants were not significant at $5 \mathrm{~cm}$ soil depth. At $15 \mathrm{~cm}$ soil depth, there was no significant differences in penetration resistance across the plant row between the two tillage methods (Fig. 6).

Tests for compacted soil layers using a trowel to supplement penetration measurements indicated no systematic trends (Fig. 7a). Tests for differences in capillary conductivity, revealed scattered lenses and bands in the top 30-40 cm of the profiles (Fig. 7b). Although not quantified, surface crusts between rip lines and planting basins appear to be common in conservation tillage (Fig. 7c).

Root distribution. Average numbers for first-order seminal and nodular roots in the squares of all soil profiles under conservation tillage and conventional tillage are presented in Tables 1 and 2 , respectively. The numbers of large roots under conservation tillage tended to be higher than under conventional tillage.

The ratios of root distribution indices for large roots under conservation tillage versus conventional tillage do not show any indication of large roots having a greater tendency of growing deeper under conservation tillage than under conventional tillage. The ratios are statistically not different from 1.00 (Fig. 8a and $8 b)$.

Average numbers for secondary (fine) roots in the squares of all soil profiles under conservation tillage and conventional tillage are shown in Table 3 and Table 4, respectively. Maize roots under conservation tillage were higher than under conventional tillage for a couple of the soil squares.

Ratios of root distribution indices for fine roots between conservation tillage and conventional tillage (Fig. 9a-d) for four horizontal distances from the plants at six soil depths were not statistically different from 1.00. 

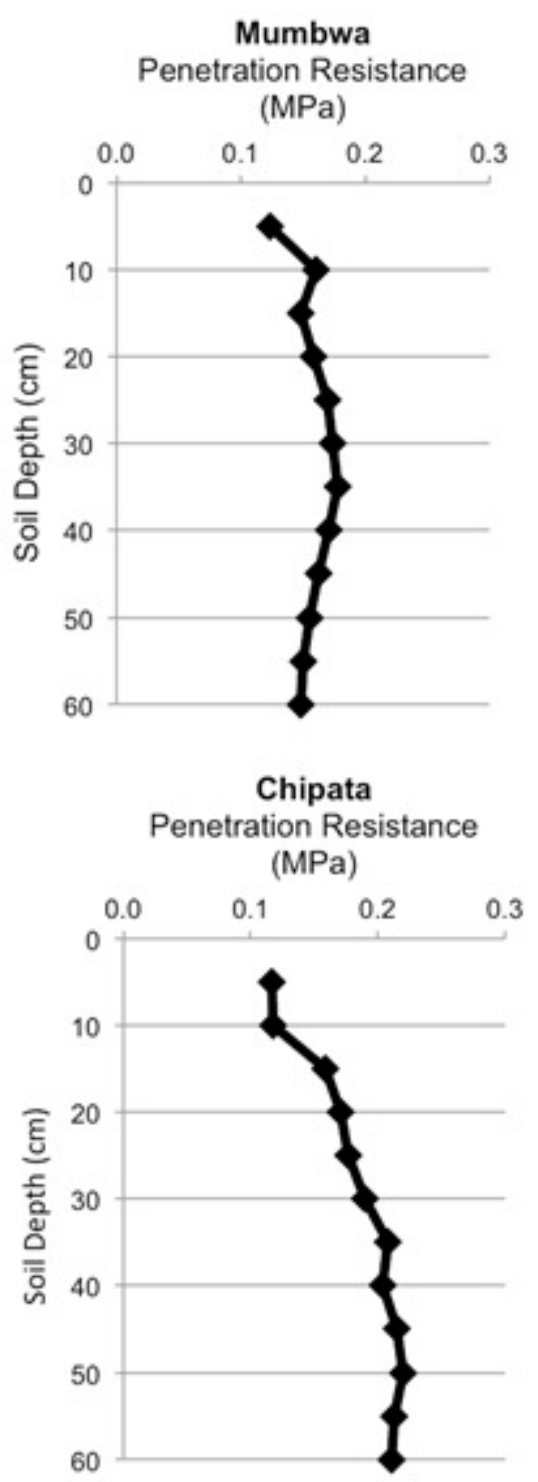

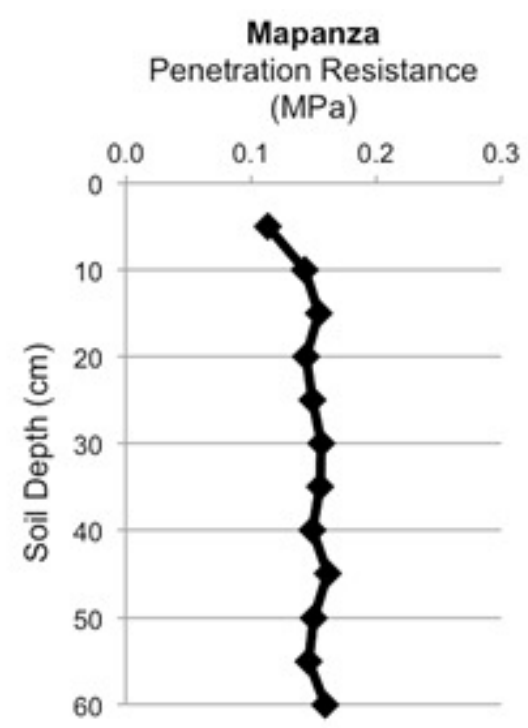

Average for All Areas

Penetration Resistance (MPa)

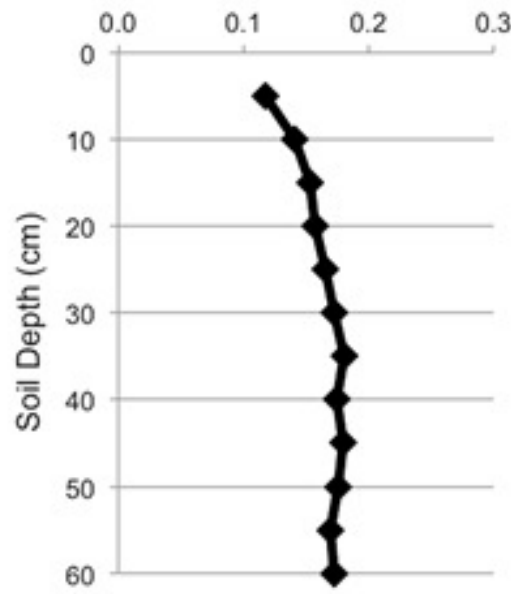

Figure 4. Average penetration resistance for soils in the Mumbwa area ( 13 soils), Mapanza ( 13 soils) and Chipata (6 soils) study areas and average values for all areas.

Soil chemical parameters. The studied soils had $\mathrm{pH}$ in the range 4.0 - 6.8. Lowest $\mathrm{pH}$ values were generally found within 30 and $60 \mathrm{~cm}$ depths. Most samples (72\%), had $\mathrm{pH}$ between 4.5 and 5.5. Only $6 \%$ were below 4.5. There was no difference in soil $\mathrm{pH}$ between conservation and conventional tillage.

Average aluminium saturation (exchangeable $\mathrm{Al} / \mathrm{CEC}$ ) in the studied soils ranged from 3 to $6 \%$
(Fig. 10a). Only 17 soil samples had values higher than $10 \%$, most of which were within $50-60 \mathrm{~cm}$ soil depth. No difference in Al saturation was found in soils under conservation and conventional tillage.

Correlations between the fine root distribution index and $\mathrm{Al}$ saturation were generally negative, but none of them were statistically significant. Similarly, acidity saturation $\left[\left(\mathrm{exch} . \mathrm{H}^{+}+\mathrm{exch}\right.\right.$. 


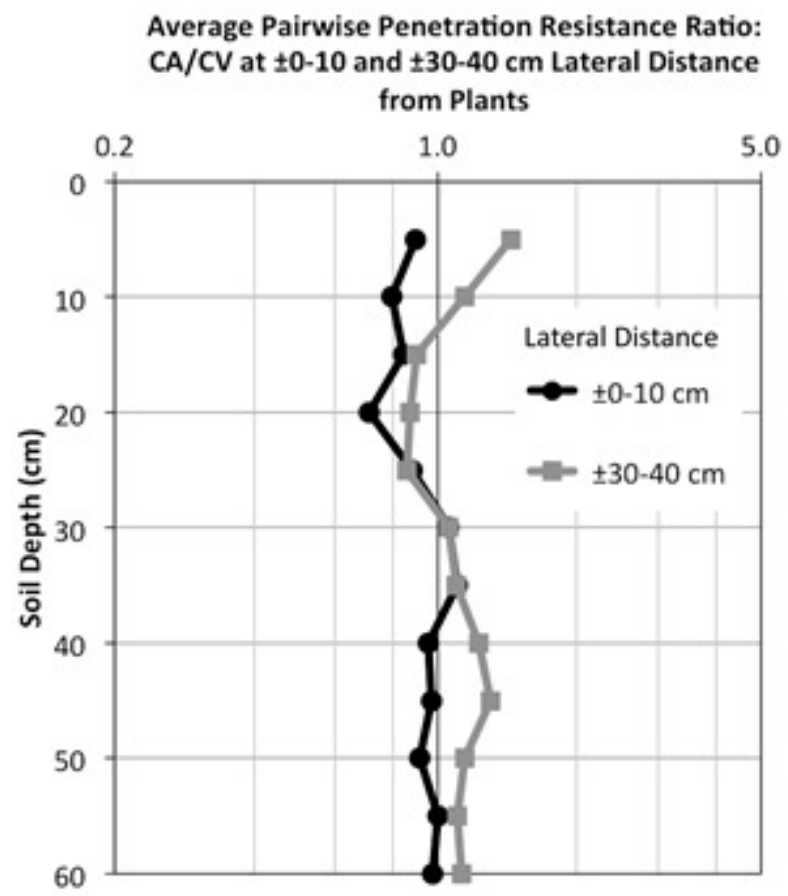

Figure 5. Average pairwise ratios of penetration resistance for conservation tillage compared to conventional tillage (ratios of 17 soil pairs). Only the ratio at $5 \mathrm{~cm}$ soil depth and $\pm 30-40 \mathrm{~cm}$ lateral distance is statistically different from $1(P=0.026)$.

$\left.\left.\mathrm{Al}^{3+}\right) / \mathrm{CEC}\right]$ showed no significant correlation with tillage or root distribution index.

Concentrations of total $\mathrm{N}$ were low in all samples (Fig. 10b). The average total $\mathrm{N}$ concentration for all sites and all depths was 0.10 $\%$, with a standard deviation of 0.05 . Concentrations were similar for conservation tillage and conventional tillage. No systematic variation could be observed with soil depth. There was also no apparent correlation between total $\mathrm{N}$ and root distribution index.

Concentrations of extractable (plant available) $\mathrm{P}$ were low to very low (Fig. 10c). Eighty-eight percent of the samples had extractable $\mathrm{P}$ below $10 \mathrm{mg} \mathrm{kg}^{-1}$. Eighty-two percent had $\mathrm{P}$ values below $5 \mathrm{mg} \mathrm{kg}^{-1}$. Extractable phosphorus was statistically different between conservation tillage $(6.3 \mathrm{mg}$ $\left.\mathrm{kg}^{-1}\right)$ and conventional tillage $\left(8.3 \mathrm{mg} \mathrm{kg}^{-1}\right)$ only at $0-10 \mathrm{~cm}$ soil depth $(\mathrm{P}=0.027)$. There was a significant positive correlation between root distribution index and extractable $\mathrm{P}$ in the topsoil $(\mathrm{r}=0.53)$. At greater soil depth, the correlation coefficient was also positive, but not significant and decreasing to zero at $50-60 \mathrm{~cm}$ depth.

\section{DISCUSSION}

Penetration resistance. Penetration resistance values were low compared to those reported from Malawi by Materechera and Mloza-Banda (1997), the latter ranging from 0.25 to $2.2 \mathrm{MPa}$. The differences in resistance levels may largely be due to differences in measurement methods. Whereas soil profiles in this study were given even moisture close to field capacity before penetrometer readings, the measurements by Materechera and Mloza-Banda appear to have been done at ambient soil moisture. Since soil penetration resistance varies exponentially with soil moisture (Canarache, 1990; Vaz et al., 2011), resistance data without corresponding soil moisture data convey limited information.

Maximum axial root growth pressure for maize has been reported to be in the range of 1.1-1.5 MPa (Gill and Bolt, 1955; Aggarwal and Prihar, 1975 ) and 0.43 MPa in newer literature (Clark and Barraclough, 1999). According to Misra et al. (1986), maximum pressures for pea (Pisum sativum L.), cotton (Gossypium hirsutum L.) and 

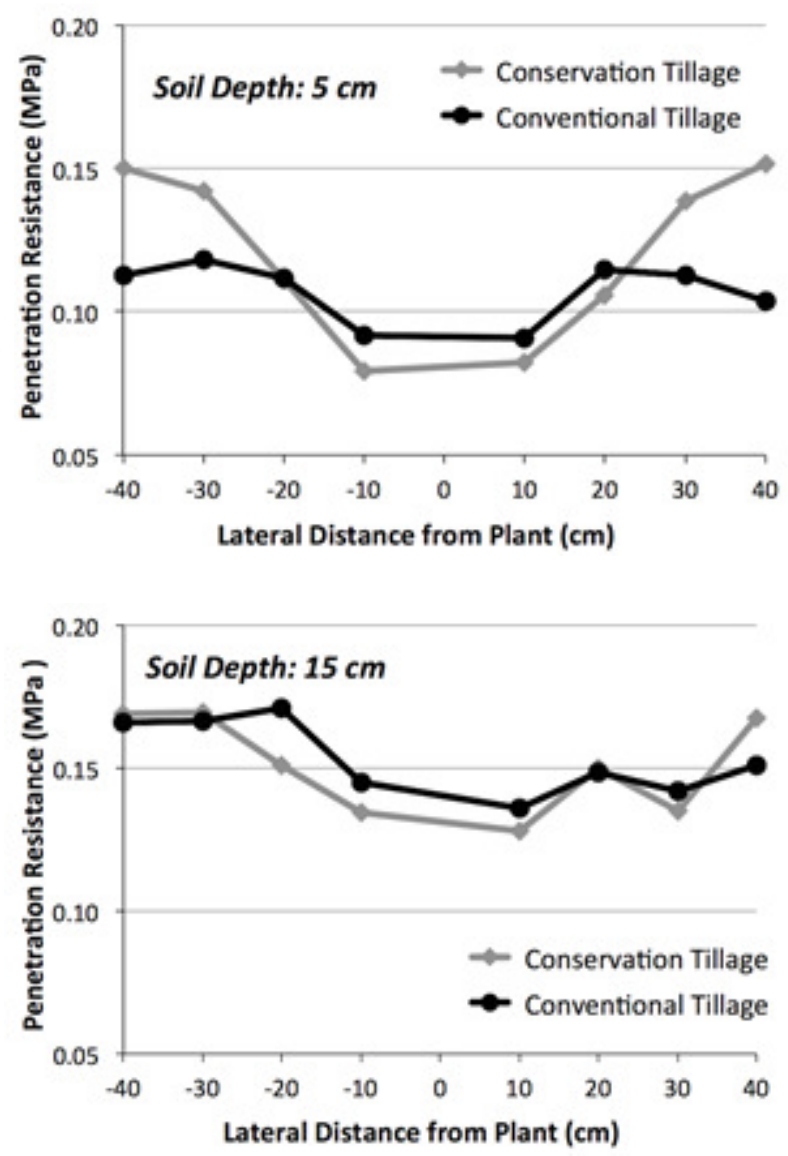

Figure 6. Average penetration resistance for conservation and conventional tillage at 5 and $15 \mathrm{~cm}$ soil depths $(n=32)$. Only the values at $\pm 40 \mathrm{~cm}$ lateral distance at $5 \mathrm{~cm}$ soil depth are statistically different $(P=0.042)$.

sunflower (Helianthus annuus L.) were 0.50, 0.29 and 0.24 MPa, respectively. Taylor and Brar (1991) showed that root elongation rate for groundnut (Arachis hypogaea L.) decreased by about $20 \%$ when soil penetration resistance increased from 0.1 to $1.0 \mathrm{MPa}$. The measurements for this study are well within this range.

The penetration resistance measurements in the wetted soils of this study, ranged mostly from 0.1 to $0.2 \mathrm{MPa}$, with the highest readings at 30 to $40 \mathrm{~cm}$ depth (Fig. 4). This proves that the soils do not harbour tillage induced hardpans capable of restricting root growth. Given sufficient soil moisture, maize roots in the studied soils were not likely to experience major physical constraints to soil penetration, except in some of the subsoils. This interpretation is confirmed by the subjective trowel test (Fig. 7a)
Consistent with the penetration measurements and trowel tests, the lenses and bands of lower conductivity did not correspond with potential hardpans caused by tillage (Fig. $7 b$ ). The lenses and bands reflected differences in soil parent material and differences in clay migration during soil formation. These results support observations of no hardpans by Umar (2012) in the same regions of Zambia.

Higher penetration resistance in the topsoil under reduced tillage found in this study (Fig. 6) is consistent with data presented by Steyn et al. (1995), which showed higher penetration resistance in the top $20 \mathrm{~cm}$ of soils under minimum tillage, compared to conventional tillage. The current data are also consistent with Steyn et al. (1995) in that the differences in penetration resistance between the tillage methods were not 

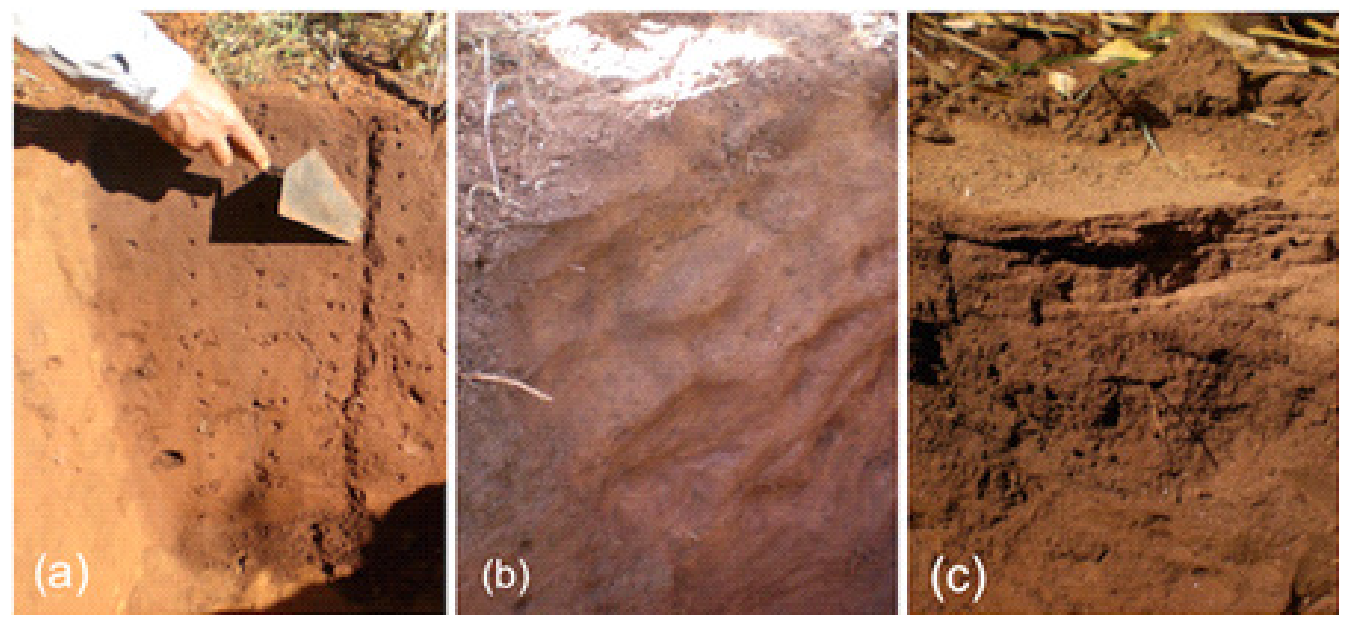

Figure 7. Example of manual test for hardpan as supplement to penetration resistance measurements (a), vertical soil relief emerging upon gently scraping away moist soil after wetting revealing irregular, protruding lenses and bands at all soil depths (b), and surface crusting under conservation tillage with no soil cover (c).

TABLE 1. Number of first order seminal and nodular (large) roots in each soil profile squares under conservation tillage in Central, Southern and Eastern Provinces in Zambia $(n=14)$

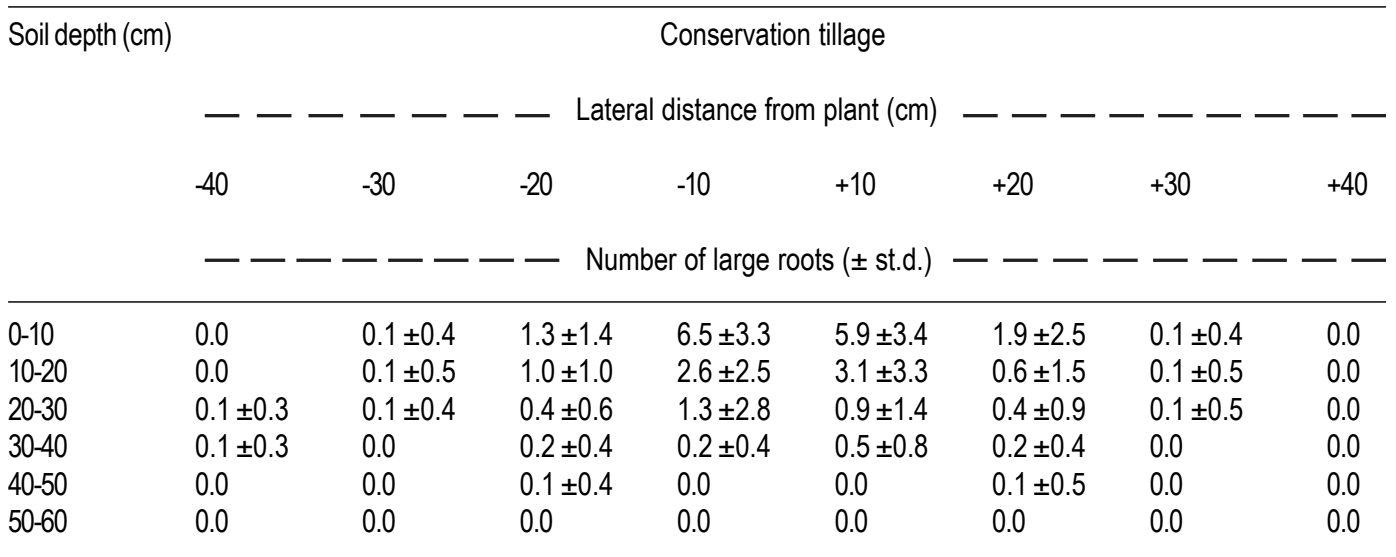

large enough to influence root growth significantly.

The penetrometer measurements did not capture potential surface crusting. Crusting of the surface appears to be common in fields with conservation tillage and no soil cover. Both impact of raindrops and human traffic seem to have formed a $1-3 \mathrm{~cm}$ surface crust in several of the studied fields. Field observations indicate that mechanical weeding using either hand hoe or oxdrawn cultivator breaks surface crust one to three times during the cropping season under conventional tillage.

Distribution of roots. Root distribution indices for both large and fine roots indicated no difference in root development between conservation tillage and conventional tillage (Figs. 8 and 9). The data are consistent with the absence of perceived hardpans in the studied soils. 
TABLE 2. Number of first order seminal and nodular (large) roots in each soil profile squares under conventional tillage in Central, Southern and Eastern Provinces in Zambia $(n=14)$

\begin{tabular}{|c|c|c|c|c|c|c|c|c|}
\hline \multirow[t]{3}{*}{ Soil depth (cm) } & \multicolumn{8}{|c|}{ Conservation tillage } \\
\hline & \multicolumn{5}{|c|}{------- Lateral distance from plant $(\mathrm{cm})$} & \multicolumn{3}{|c|}{--------} \\
\hline & -40 & -30 & -20 & -10 & +10 & +20 & +30 & +40 \\
\hline & \multicolumn{5}{|c|}{-------- Number of large roots $( \pm$ st.d. $)$} & \multicolumn{3}{|c|}{---------} \\
\hline $0-10$ & 0.0 & $0.2 \pm 0.6$ & $2.3 \pm 3.0$ & $5.9 \pm 2$ & $5.2 \pm 2.5$ & $0.9 \pm 1.0$ & $0.1 \pm 0.5$ & $0.1 \pm 0.3$ \\
\hline $10-20$ & $0.1 \pm 0.3$ & $0.2 \pm 0.4$ & $0.2 \pm 0.4$ & $2.4 \pm 1.5$ & $2.4=$ & $0.9 \pm 0.9$ & $0.2 \pm 0.4$ & 0.0 \\
\hline $20-30$ & 0.0 & $0.1 \pm 0.3$ & $0.1 \pm 0.4$ & $0.6 \pm 0.9$ & $0.8 \pm 1.2$ & $0.1 \pm 0.3$ & $0.1 \pm 0.3$ & 0.0 \\
\hline $30-40$ & 0.0 & 0.0 & $0.1 \pm 0.3$ & $0.2 \pm 0.6$ & $0.2 \pm 0.6$ & 0.0 & $0.1 \pm 0.3$ & 0.0 \\
\hline $40-50$ & 0.0 & 0.0 & 0.0 & $0.1 \pm 0.3$ & 0.0 & 0.0 & 0.0 & 0.0 \\
\hline $50-60$ & 0.0 & 0.0 & 0.0 & $0.1 \pm 0.3$ & 0.0 & 0.0 & 0.0 & 0.0 \\
\hline
\end{tabular}

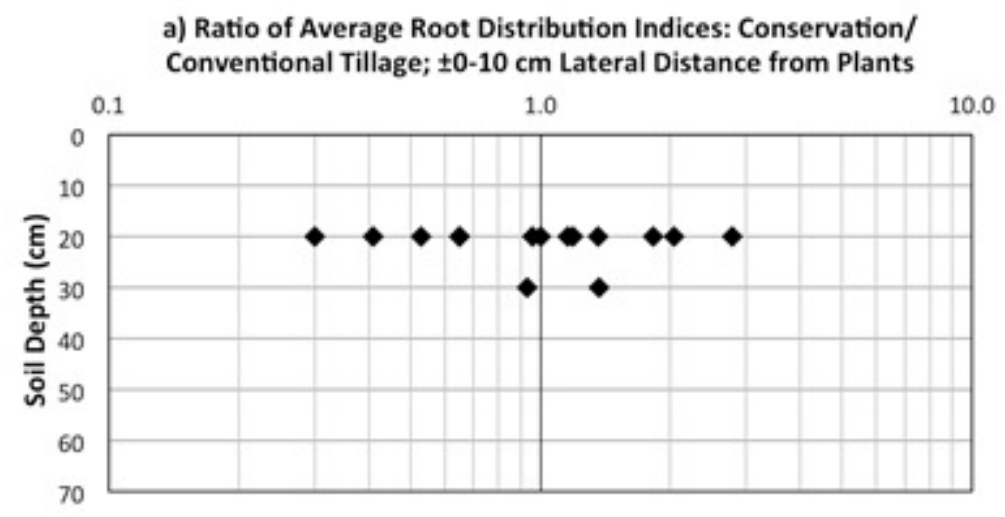

b) Ratio of Average Root Distribution Indices: Conservation/ Conventional Tillage; $\pm \mathbf{1 0 - 2 0} \mathrm{cm}$ Lateral Distance from Plants

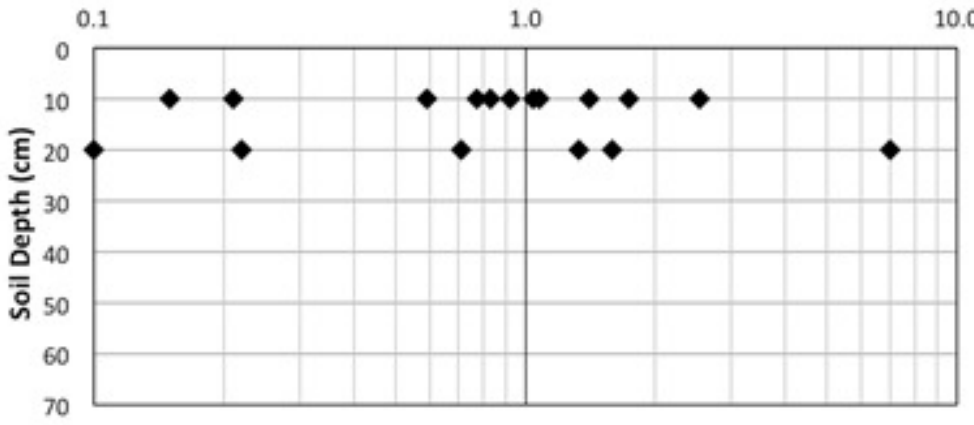

Figure 8. Ratios of average large root distribution indices for two sides of the of the maize plants under conservation tillage relative to conventional tillage at $\pm 0-10 \mathrm{~cm}(\mathrm{a}), \pm 10-20 \mathrm{~cm}$ (b) lateral distance from the center of the plants and at six soil depths. 
TABLE 3. Number of second order (fine) roots in each soil profile squares under conservation tillage in Central, Southern and Eastern Provinces in Zambia ( $=14$ )

\begin{tabular}{|c|c|c|c|c|c|c|c|c|}
\hline \multirow[t]{4}{*}{ Soil depth (cm) } & \multicolumn{8}{|c|}{ Conservation tillage } \\
\hline & \multicolumn{3}{|c|}{-------} & \multicolumn{2}{|c|}{ Lateral distance from plant (cm) } & \multirow{2}{*}{$\begin{array}{r}--- \\
+20\end{array}$} & \multicolumn{2}{|c|}{-----} \\
\hline & -40 & -30 & -20 & -10 & +10 & & +30 & +40 \\
\hline & --- & --- & -- & mber of large & roots ( \pm st.d.) & --- & --- & -- \\
\hline $0-10$ & $13.5 \pm 14.2$ & $19.2 \pm 17.9$ & $39.8 \pm 36.5$ & $126 \pm 73.4$ & $127 \pm 85.1$ & $49.9 \pm 58.6$ & $23.4 \pm 27.2$ & $10.1 \pm 11.5$ \\
\hline $10-20$ & $7.7 \pm 8.3$ & $11.3 \pm 8.3$ & $24.1 \pm 27.4$ & $55.0 \pm 57.5$ & $48.1 \pm 51.9$ & $25.0 \pm 40.7$ & $10.4 \pm 11.1$ & $6.1 \pm 5.2$ \\
\hline $20-30$ & $3.1 \pm 3.6$ & $5.9 \pm 3.6$ & $10.6 \pm 8.6$ & $17.6 \pm 12.0$ & $16.6 \pm 11.2$ & $9.6 \pm 5.5$ & $6.9 \pm 4.1$ & $3.7 \pm 4.4$ \\
\hline $30-40$ & $2.4 \pm 2.6$ & $4.9 \pm 2.6$ & $8.2 \pm 7.7$ & $9.9 \pm 7.3$ & $9.3 \pm 5.5$ & $6.4 \pm 6.5$ & $4.1 \pm 4.5$ & $2.8 \pm 3.6$ \\
\hline $40-50$ & $1.4 \pm 2.6$ & $3.6 \pm 2.6$ & $3.2 \pm 4.4$ & $5.7 \pm 3.4$ & $5.4 \pm 2.9$ & $6.1 \pm 7.2$ & $2.2 \pm 2.8$ & $2.9 \pm 4.5$ \\
\hline $50-60$ & $1.0 \pm 1.9$ & $0.9 \pm 1.9$ & $2.2 \pm 2.6$ & $3.6 \pm 3.8$ & $3.1 \pm 1.3$ & $1.8 \pm 2.6$ & $0.9 \pm 1.4$ & $1.7 \pm 2.4$ \\
\hline
\end{tabular}

TABLE 4. Number of second order (fine) roots in each soil profile squares under conventional tillage in Central, Southern and Eastern Provinces in Zambia ( $\mathrm{n}=14)$

\begin{tabular}{|c|c|c|c|c|c|c|c|c|}
\hline \multirow[t]{4}{*}{ Soil depth (cm) } & \multicolumn{8}{|c|}{ Conservation tillage } \\
\hline & \multicolumn{5}{|c|}{ 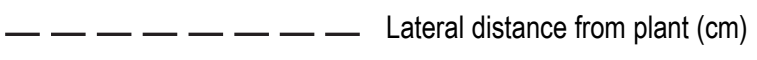 } & \multicolumn{3}{|c|}{---------} \\
\hline & -40 & -30 & -20 & -10 & +10 & +20 & +30 & +40 \\
\hline & \multicolumn{5}{|c|}{-------} & \multicolumn{3}{|c|}{-------} \\
\hline $0-10$ & $10.1 \pm 6.8$ & $13.9 \pm 12.0$ & $34.1 \pm 21.8$ & $96.2 \pm 68.1$ & $106 \pm 92.6$ & $35.1 \pm 29.2$ & $17.9 \pm 21.3$ & $11.1 \pm 12.0$ \\
\hline $10-20$ & $5.5 \pm 4.3$ & $8.3 \pm 5.9$ & $15.3 \pm 9.0$ & $31.9 \pm 26.7$ & $30.4 \pm 25.9$ & $16.6 \pm 10.4$ & $9.1 \pm 6.8$ & $4.9 \pm 5.3$ \\
\hline $20-30$ & $4.6 \pm 4.4$ & $3.3 \pm 3.1$ & $8.5 \pm 4.6$ & $11.0 \pm 7.2$ & $9.8 \pm 6.4$ & $7.2 \pm 4.0$ & $3.3 \pm 2.2$ & $3.1 \pm 2.4$ \\
\hline $30-40$ & $2.1 \pm 3.2$ & $2.1 \pm 2.1$ & $5.2 \pm 3.5$ & $6.1 \pm 3.5$ & $6.2 \pm 4.3$ & $3.8 \pm 2.8$ & $4.1 \pm 3.4$ & $2.2 \pm 2.6$ \\
\hline $40-50$ & $1.5 \pm 1.3$ & $2.1 \pm 2.7$ & $2.7 \pm 1.8$ & $3.3 \pm 2.6$ & $4.0 \pm 3.8$ & $2.2 \pm 2.8$ & $1.6 \pm 2.8$ & $1.5 \pm 2.5$ \\
\hline $50-60$ & $0.6 \pm 1.2$ & $1.1 \pm 1.6$ & $1.3 \pm 1.8$ & $2.7 \pm 2.1$ & $2.2 \pm 1.7$ & $1.5 \pm 1.7$ & $0.7 \pm 1.3$ & $0.9 \pm 1.3$ \\
\hline
\end{tabular}

Both under conservation and conventional tillage, maize roots were concentrated in a relatively small volume of about $0.03 \mathrm{~m}^{3}$. In comparison, root volumes of single maize plants in deep, fertile soils elsewhere in the world may be in the order of $5 \mathrm{~m}^{3}$ to $6 \mathrm{~m}^{3}$ (Feldman, 1994). In the studied Zambian soils, there were relatively few fine roots beyond $20-30 \mathrm{~cm}$ from the base of the plants, vertically and horizontally. The roots were apparently limited to the soil volume directly affected by application of fertiliser, lime and plant residues. The small root volumes represent a yield limitation due to restricted possibilities for uptake of water and nutrients. On the other hand, high root density in a small soil volume may lead to high uptake efficiency of plant nutrients added locally around the plant (Füleky and Nooman, 1991). In contrast with the current results, Azevedo et al. (2011) found significantly higher root development in sugarcane at $10-50 \mathrm{~cm}$ soil depth in ploughed fields compared to minimum tillage and direct planting. Water uptake was correspondingly higher under conventional tillage.

Soil chemical properties. Since the confinement of the roots of the studied maize plants did not seem to be caused by physical restrictions, 
a) Ratio of Average Root Distribution Indices: Conservation/ Conventional Tillage; \pm 0 -10 cm Lateral Distance from Plants

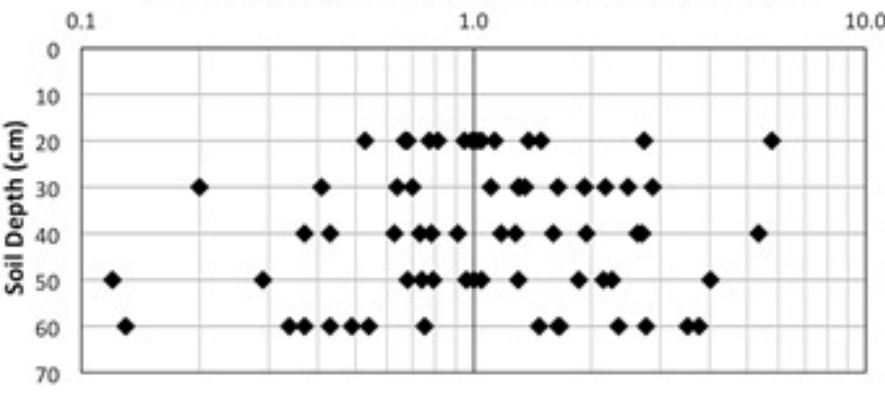

b) Ratio of Average Root Distribution Indices: Conservation/ Conventional Tillage; $\pm 10-20 \mathrm{~cm}$ Lateral Distance from Plants

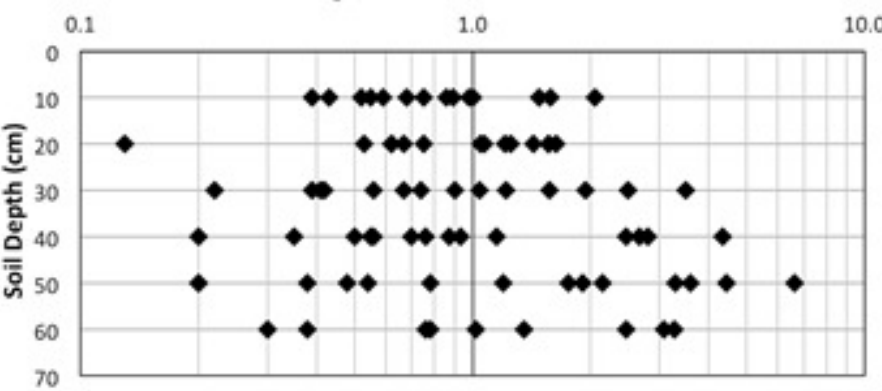

c) Ratio of Average Root Distribution Indices: Conservation/ Conventional Tillage; \pm 20 - $30 \mathrm{~cm}$ Lateral Distance from Plants

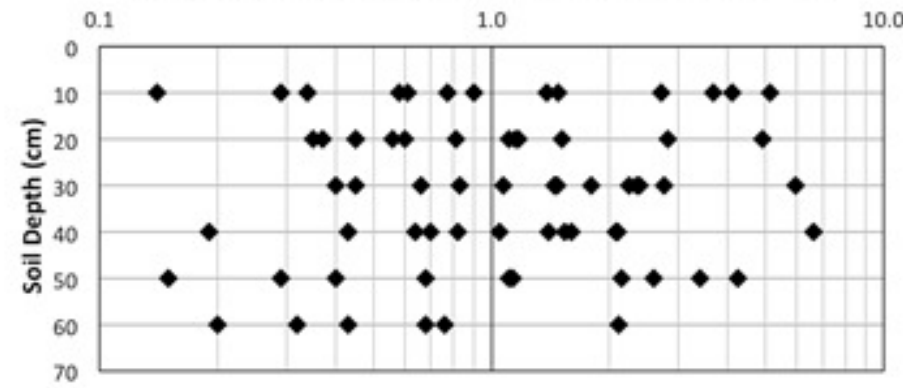

d) Ratio of Average Root Distribution Indices: Conservation/ Conventional Tillage; $\pm 30-40 \mathrm{~cm}$ Lateral Distance from Plants

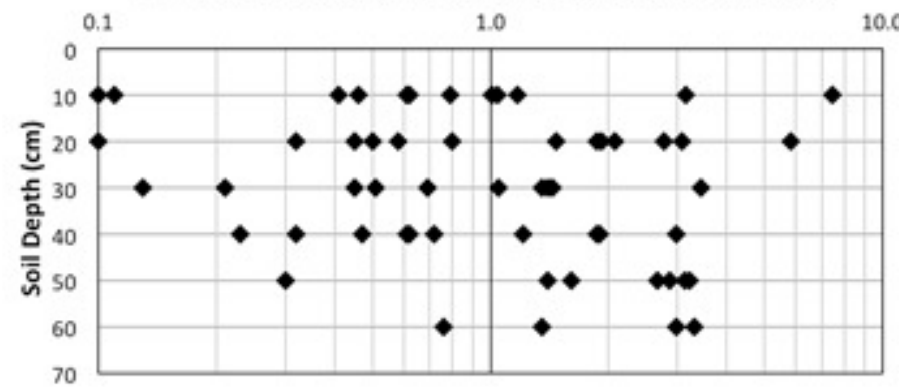

Figure 9. Ratios of average fine root distribution indices for two sides of the maize plants under conservation tillage relative to conventional tillage at $\pm 0-10 \mathrm{~cm}(\mathrm{a}), \pm 10-20 \mathrm{~cm}$ (b) $, \pm 20-30 \mathrm{~cm}(\mathrm{c}), \pm 30-40 \mathrm{~cm}$ (d) lateral distance from the center of the plants and at six soil depths. 

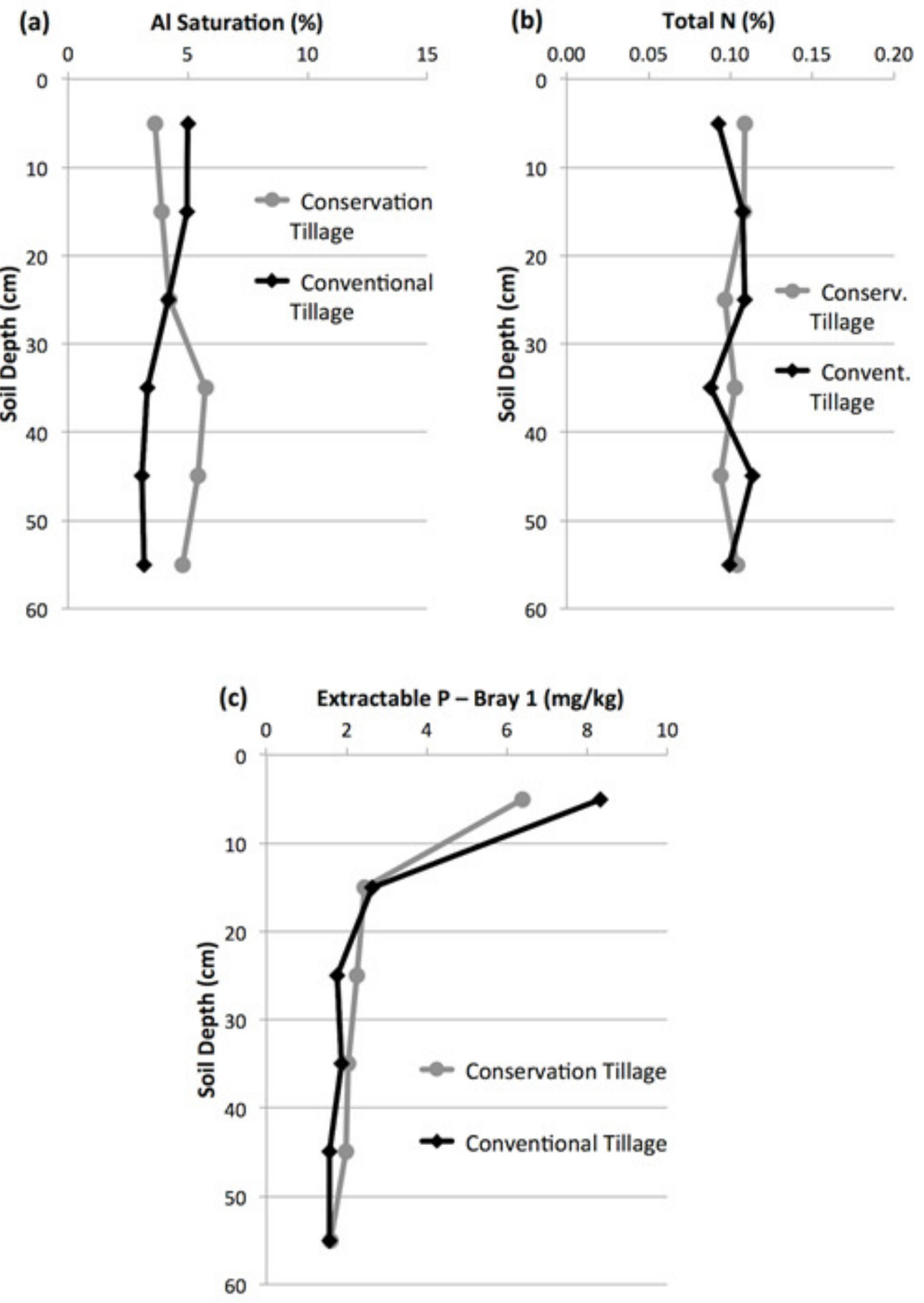

Figure 10. Vertical distribution of exchangeable Al saturation (a), extractable $\mathrm{P}($ Bray-1) (b), and total $\mathrm{N}$ between maize rows (c) under conservation and conventional tillage; average for all regions $(n=32)$. None of the values for conservation tillage are statistically different from the corresponding values for conventional tillage. 


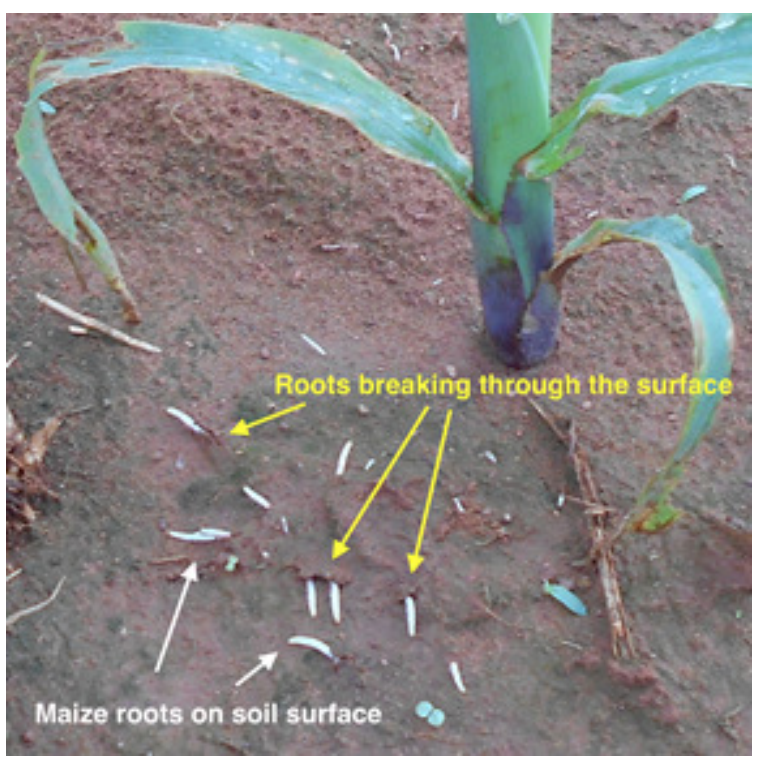

Figure 11. Maize roots penetrating the soil surface after topdressing of urea under conservation tillage (ripping with no ridging).

\begin{tabular}{|c|c|c|c|c|c|c|}
\hline \multirow{3}{*}{$\begin{array}{l}\text { Soil Depth } \\
\quad(\mathrm{cm})\end{array}$} & \multicolumn{6}{|c|}{ Soil Moisture (\%) } \\
\hline & \multicolumn{3}{|c|}{ Soil \#1 } & \multicolumn{3}{|c|}{ Soil \#2 } \\
\hline & Nov. 17 & Nov. 24 & Dec. 1 & Nov. 17 & Nov. 24 & Dec. 1 \\
\hline $00-10$ & 6.4 & 9.9 & 18.3 & 5.6 & 7.5 & 14.7 \\
\hline $10-20$ & 4.2 & 8.8 & 20.4 & 3.7 & 5.3 & 20.5 \\
\hline $20-30$ & \multirow{4}{*}{$\begin{array}{c}\text { Dry, hard } \\
\text { soil }\end{array}$} & 3.9 & 23.2 & \multirow{4}{*}{$\begin{array}{c}\text { Dry, hard } \\
\text { soil }\end{array}$} & \multirow{4}{*}{$\begin{array}{c}\text { Dry, hard } \\
\text { soil }\end{array}$} & 18.9 \\
\hline $30-40$ & & \multirow{3}{*}{$\begin{array}{c}\text { Dry, hard } \\
\text { soil }\end{array}$} & 18.8 & & & 20.6 \\
\hline $40-50$ & & & 10.8 & & & 17.8 \\
\hline $50-60$ & & & Dry, h. soil & & & Dry, h. soil \\
\hline
\end{tabular}

Figure 12. Two examples of soil moisture at different soil depths during the first three weeks of the 2013/14 rainy season for selected soils at the Mumbwa study area.

chemical properties of the soils might have played a greater role. Nutrient availability can have a variety of effects on root development. For instance, Islam et al. (1980) showed that the ratio of root biomass to aboveground biomass of maize decreased with decreasing soil $\mathrm{pH}$ in the range of 4.0 to 8.5. Elongation of maize roots is generally known to be restricted by high concentrations of dissolved aluminum (Vázquez et al., 1999), with different varieties having different tolerance levels to Al saturation (Giaveno and Miranda Filho, 2000; Piñeros and Kochian, 2001). Soil N concentrations have also been shown to influence root morphology in maize, with large genotype differences (Chun et al., 2005). The effects of $\mathrm{N}$ on root distributions are, however, diverse. Bloom et al. (2006) concluded that elongation of maize roots in nutrient solutions increased with N availability. Durieux et al. (1994) showed that total root weight declined as $\mathrm{N}$ application increased. High $\mathrm{N}$ supply appears to reduce root elongation (Wang et al., 2008); whereas $\mathrm{N}$ deficiency increases axial root lengths, although with a reduced number of roots (Chun 
et al., 2005; Gao et al., 2015). Root branching is stimulated by ample $\mathrm{N}$ supply (Eghball et al., 1993). On the other hand, low concentrations of available $\mathrm{P}$ tend to restrict root elongation (Mollier and Pellerin, 1999).

The current data suggest that significant yield reductions due to $\mathrm{pH}$ may not be likely (Farina and Channon, 1991; Aune and Lal, 1997). However, in view of the data presented by Islam et al. (1980), root biomass may potentially be suppressed relative to aboveground biomass at $\mathrm{pH}$ in the measured range (4.0-6.8). Data for root distribution index and soil $\mathrm{pH}$ showed no significant correlations. Correlation coefficients between root distribution indices and total $\mathrm{N}$ were highest for the topsoil ( $r=0.37$; non-significant) decreasing to zero with depth.

The Al saturation of 3 to $6 \%$ in the studied soils may not represent an appreciable limitation to root growth. The numbers were low compared to critical values reported in the literature (Aune and Lal, 1997). Aluminium saturation between 20 and $40 \%$ has been shown to result in maize yield reductions in Kwazulu-Natal in the order of 10 to $50 \%$, respectively (Farina and Channon, 1991). Critical values for Al toxicity are, however, difficult to establish due to interactions between $\mathrm{Al}$ and dissolved compounds, clay minerals and organic matter (Foy, 1984).

The unfertilised soil between maize rows had low total $\mathrm{N}$ concentrations $(0.1 \%)$. The combination of concentrated fertiliser application in a small soil volume around the maize plant and low total $\mathrm{N}$ elsewhere in the soil, is a likely contributing factor for the limited root distribution. Surface application of urea as topdressing in conservation agriculture leads frequently to roots growing upwards and penetrating the soil surface (Fig. 11). The consistently low total $\mathrm{N}$ concentrations in all soils and at all depths between plant rows were not conducive for quantifying the effect of nitrogen on root distribution in the studied soils.

The values for extractable $\mathrm{P}$ between plant rows in the studied fields, indicate severe limitation for crop growth. Values around $10 \mathrm{mg}$ $\mathrm{kg}^{-1}$ might be considered to be the critical level for yield reductions in maize in these soils (Aune and Lal, 1997). Expected relative maize yields in unfertilised soils may be around 40-50\% of potential yield according to data for critical levels from Nigeria (Adeoye and Agboola, 1985). Even lower relative yields may be expected based on data for Oxisols in Brazil (Smyth and Cravo, 1990) and data from South Africa (Schmidt et al., 2007). Below the 10 to $20 \mathrm{~cm}$ soil depth, the extractable $P$ concentrations were generally around $2 \mathrm{mg}$ $\mathrm{kg}^{-1}$ for both conservation and conventional tillage (Fig. 10c). The slightly higher values for $\mathrm{P}$ in the topsoil under conventional tillage compared to conservation tillage, might be expected since fertilised and unfertilised soil material were mixed during ploughing and formation of ridges. The difference between conservation and conventional tillage is, however, not statistically significant. Concentrations of plant nutrients in rip lines and basins were not measured, but were probably higher than in the mid-rows due to annual, localised fertiliser application.

Root deformations. Photos presented in the literature from eastern and southern Africa of Lshaped taproots (Douglas et al., 1999; Baudron et al., 2007) bear strong testimonies of physical constraints to root elongation. However, in both publications, only the taproots seemed to be bent, whereas secondary roots emanating from the taproots, grew downward apparently without notable physical resistance. Thus, the physical constraints appear to have been temporary.

A simple explanation to this phenomenon might rest in the relative downward movement of roots compared to movement of soil water early in the cropping season. While maize may have an initial root elongation rate of 5-6 $\mathrm{cm}^{-1}$ day $^{-1}$ (Weaver, 1925), and $4.5 \mathrm{~cm} \mathrm{day}^{-1}$ for groundnut (Huang and Ketring, 1987), the downward movement of the wetting fronts in soils during early stages of the rain season, might be substantially lower. For instance, in one of the soils in this study, the wetting front moved around $2 \mathrm{~cm}$ day $^{-1}$ during the first two weeks of the 2013/ 14 season (Soil \#1 in Fig. 12). In another soil, the wetting front remained stagnant at about 15-20 $\mathrm{cm}$ depth, for about two weeks due to a rain event followed by a dry spell (Soil \#2 in Fig. 12). Potentially, a maize root might grow 35 to $70 \mathrm{~cm}$ in one to two weeks. Thus, primary roots may reach dry, impenetrable soil horizons within a few days after seed germination, leading to horizontal 
growth at the interphase between moist and dry soil. Later, when the wetting front in the soil has progressed further downwards, secondary roots may be able to grow vertically, unobstructed by hard soil.

\section{CONCLUSION}

No cultivation-induced hardpans (plough/hoe pans) capable of restricting root growth existed in the studied soils in the Central, Southern and Eastern Provinces of Zambia. Between maize rows, soils under conservation tillage are more compact at $5 \mathrm{~cm}$ depth than soils under conventional tillage. Other than that, there are no differences between conservation and conventional tillage in terms of penetration resistance at any soil depth. Although not quantified, surface crusts at $0-3 \mathrm{~cm}$ depth appears to be more common in soils under conservation tillage than conventional tillage. No difference could be detected in maize root distribution under conservation tillage and conventional tillage. In all fields, maize roots are confined to small soil volumes. The confinement of roots appears to be influenced by low chemical soil fertility, notably low $\mathrm{P}$ and $\mathrm{N}$ concentrations. Aluminium saturation (Al toxicity) is relatively low in these soils and has, therefore, probably less impact on root growth than concentrations of $\mathrm{P}$ and N. Deformation of taproots in soils under unmechanised tillage, reported in the literature, may be caused by temporarily dry subsoil early in the rain season, rather than by permanent plough pans. Thus, there is no reason for extension agencies to continue advising farmers in the study areas to rip or dig planting basins in order to "break the hardpan" for better root growth.

\section{ACKNOWLEDGEMENT}

This study was part of the "Conservation Agriculture Research and Evaluation Programme" (CAREP) funded by the Norwegian Ministry of Foreign Affairs, through the Conservation Farming Unit (CFU), Zambia. Soil chemical analyses were conducted by the Department of Soil Science, University of Zambia. The paper has benefitted from constructive comments by
Professor Jens B. Aune, Norwegian University of Life Sciences.

\section{REFERENCES}

Adeoye, G.O. and Agboola, A.A.1985. Critical levels for soil $\mathrm{pH}$, available $\mathrm{P}, \mathrm{K}, \mathrm{Zn}$ and $\mathrm{Mn}$ and maize ear-leaf content of $\mathrm{P}, \mathrm{Cu}$ and $\mathrm{Mn}$ in sedimentary soils of South-Western Nigeria. Fertilizer Research 6:65-71.

Aggarwal, G.C. and Prihar, S.S.1975. A simple technique to determine axial root growth force. Plant and Soil 42:485-489.

Aune, J.B. and Lal, R. 1997. Agricultural productivity in the tropics and critical limits of properties of Oxisols, Ultisols, and Alfisols. Tropical Agriculture 74:96-103.

Avornyo, V.K., Adjadeh, T.A. and Amatekpor, J.K. 2013. Morphological, chemical and physical properties of two pan soils in the Lower Volta Basin of Ghana. West African Journal of Applied Ecology 21(2):63-77.

Azevedo, M.C.B., Chopart, J.L. and Medina, C.C. 2011. Sugarcane root length density and distribution from root intersection counting on a trench-profile. Scientia Agricola (Piracicaba, Brazil) 68(1):94-101.

Baudron, F., Mwanza, H.M.,Triomphe, B. and Bwalya, M. 2007. Conservation agriculture in Zambia: A case study of Southern Province. African Conservation Tillage Network, Centre de Coopération Internationale de Recherche Agronomique pour le Développement, FAO.

Bengough, A.G. and Mullins, C.E. 1991. Penetrometer resistance, root penetration resistance and root elongation rate in two sandy loam soils. Plant and Soil 131:59-66.

Bennie, A.T.P. and Krynauw, G.N. 1985. Causes, adverse effects and control of soil compaction. South African Journal of Plant and Soil 2(3):109-114.

Bloom, A.J., Frensch, J. and Taylor, A.R. 2006. Influence of inorganic nitrogen and $\mathrm{pH}$ on the elongation of maize seminal roots. Annals of Botany 97:867-873.

Brammer, H. 1973. Soil profile descriptions: Analytical data and an account of soil genesis and classification. Soil Survey Report No. 11, Soil Survey Unit, Mount Makulu Research Station, Chilanga, Zambia. 
Canarache, A. 1990. PENETR - a generalized semiempirical model estimating soil resistance to penetration. Soil \&Tillage Research 16:5170.

CFU. 2011. The practice of conventional and conservation agriculture in East and southern Africa. Zambia Farmers Union, Conservation Farming Unit, Lusaka, Zambia.

CFU. (undated) Zambia Conservation Agriculture Programme (CAP).

https://vtechworks.lib.vt.edu/bitstream/handle/ 10919/69066/4836 Zambia CAP. pdf?sequence=1 (accessed May 2016).

Chikowo, R. (undated). Zambia: Description of cropping systems, climate, and soils in Zambia. Global yield gap atlas. University of Nebraska, Wageningen UR and Water for Food. http://www.yieldgap.org/zambia (accessed May 2016).

Chopart, J.L. and Siband, P. 1999. Development and validation of a model to describe root length density of maize from root counts on soil profiles. Plant and Soil 214(1):61-74.

Chun, L.A., Mi, G.H., Li, J.S., Chen, F.J. and Zhang, F.S. 2005. Genetic analysis of maize root characteristics in response to low nitrogen stress. Plant and Soil 276:369-382.

Clark, L.J. and Barraclough, P.B.1999. Do dicotyledons generate greater maximum axial root growth pressures than monocotyledons? Journal of Experimental Botany 50(336):12631266.

Climatemps.com. (undated). World Climate \& Temperature.

http://www.zambia.climatemps.com (accessed Sept. 2014).

Douglas, M.G., Mughogho, S.K., Saka, A.R., Shaxson, T.F. and Evers,G.1999. An investigation into the presence of a cultivation hoe pan under smallholder farming conditions. FAO Investment Centre, Occasional Paper Series No. 10. Malawai Government, Ministry of Agriculture and Irrigation and Food, Lilongwe, and Food and Agriculture Organization, Rome, Italy.

Durieux, R.P., Kamprath, E.J., Jackson, W.A. and Moll, R.H.1994. Root distribution of corn: The effect of nitrogen fertilization. Agronomy Journal 86(6):958-952.
Eghball, B., Settimi, J.R., Maranville, J.W. and Parkhurst, A.M. 1993. Fractal analysis for morphological description of corn roots under nitrogen stress. Agronomy Journal 85(2):287289.

FAO and UNESCO. (undated). Soil Map of Zambia. http://eusoils.jrc.ec.europa.eu/ esdb archive/eudasm/africa/maps/ afr zm20011 so.htm (accessed Sept. 2014).

FAO. 2006. World Reference Base for Soil Resources 2006: A Framework for International Classification, Correlation and Communication (World Soil Resources Reports). Food and Agriculture Organization of the United Nations, Rome, Italy.

FAO. 2009. Scaling-up conservation agriculture in Africa: Strategy and approaches. FAO Sub Regional Office for Eastern Africa (SFE). Addis Ababa, Ethiopia.

Farina, M.P.W. and Channon, P. 1991. A field comparison of lime requirement indices for maize. Plant and Soil 134:127-135.

Feldman, L. 1994. The maize root. In: The Maize Handbook. M. Freeling and V. Walbot (Eds.). Springer-Verlag, New York, pp. 29-37.

Foy, C.D. 1984. Physiological effects of hydrogen, aluminum, and manganese toxicities in acid soil. In: Soil Acidity and Liming. F. Adams (Ed.). Agronomy No. 12, American Society of Agronomy, Inc. Madison, WI, USA, pp. 5797.

Füleky, G. and Nooman, H.J. 1991. Effects of soil volume on root growth and nutrient uptake. In: Plant Roots and Their Environment. McMichael, B.L. and Persson, H. (Eds.). Developments in Agricultural and ManagedForest Ecology 24: Proceedings from an ISRRsymposium, August $21^{\text {st }}-26^{\text {th }} 1988$, Uppsala, Sweden. Elsevier Science Publishing Company Inc., Amsterdam, pp. 446-448.

Gao, K., Chen, F.J., Yuan, L.X., Zhang, F.S. and Mi, G.H. 2015. A comparative analysis of root morphological changes and nitrogen allocation in maize in response to low nitrogen stress. Plant, Cell \&Environment 38:740-750.

Giaveno, C.D. and Miranda Filho, J.B. 2000. Rapid screening for aluminum tolerance in maize (Zea mays L). Genetics and Molecular Biology 23(4):847-850. 
Gill, W.R. and Bolt, G.H. 1955. Pfeffer's studies of the root growth pressures exerted by plants. Agronomy Journal 47:166-168.

Haggblade, S. and Tembo, G. 2003. Conservation farming in Zambia. EPTD Discussion Paper No. 108, International Food Policy Research Institute, Washington, USA.

Huang, M.T. and Ketring, D.L. 1987. Root growth characteristics of peanut genotypes. Journal of Agricultural Research of China 36(1):4152.

ICRAF. 2009. Creating an evergreen agriculture in Africa for food security and environmental resilience. World Agroforestry Centre, Nairobi, Kenya.

IFAD. 2011. Smallholder conservation agriculture - rationale for IFAD involvement and relevance to the east and southern Africa region. International Fund for Agricultural Development (IFAD), Rome, Italy.

Islam, A.K.M.S., Edwards, D.G. and Asher, C.J. 1980. pH optima for crop growth. Plant and Soil 54:339-357.

Lampurlanés, J. and Cantero-Martínez, C. 2003. Soil bulk density and penetration resistance under different tillage and cropmanagement systems and their relationship with barley root growth. Agronomy Journal 95:526-536.

Materechera, S.A. and Mloza-Banda, H.R. 1997. Soil penetration resistance, root growth and yield of maize as influenced by tillage system on ridges in Malawi. Soil \&Tillage Research 41:13-24.

Mazvimavi, K., Twomlow, S.,Belder, P. and Hove, L. 2008. An assessment of the sustainable uptake of conservation farming in Zimbabwe: Global theme on agroecosystems report no. 39. International Crops Research Institute for the Semi-Arid Tropics, P. O. Box 776, Bulawayo, Zimbabwe.

Misra, R.K., Dexter, A.R. and Alston, A.M. 1986. Maximum axial and radial growth pressure of plant roots. Plant and Soil 95:315-326.

Mollier, A. and Pellerin, S. 1999. Maize root system growth and development as influenced by phosphorus deficiency. Journal of Experimental Botany 50(333):487-497.

Mulholland, B. and Fullen, M.A. 1991. Cattle trampling and soil compaction on loamy sands. Soil Use and Management 7(4):189193.

Otieno, Y. 2012. Farmers in sub-Saharan Africa regenerate land to beat famine. Agroforesty World, World Agroforestry Centre.

http://blog.worldagroforestry.org/index.php/ 2012/04/16/farmers-in-sub-saharan-africaregenerate-land-to-beat-famine/ (accessed May 2016).

Piñeros, M.A. and Kochian, L.V. 2001. A patchclamp study on the physiology of aluminum toxicity and aluminum tolerance in maize. Identification and characterization of $\mathrm{Al}^{3+}$ induced anion channels. Plant Physiology 125:292-305.

Schmidt, C.J.J., Adriaanse, F.G. and du Preez, C.C. 2007. Extractable soil phosphorus threshold values for dryland maize on the South African Highveld. South African Journal of Plant and Soil 24(1):37-46.

Smyth, T.J. and Cravo, M.S. 1990. Critical phosphorus levels for corn and cowpea in a Brazilian Amazon Oxisol. Agronomy Journal 82:309-312.

SUSTAINET EA. 2010. Technical manual for farmers and field extension service providers: Conservation agriculture. Sustainable Agriculture Information Initiative, Nairobi, Kenya.

Steyn, J.T., Tolmay, J.P.C., Human, J.J. and Kilian, W.H. 1995. The effects of tillage systems on soil bulk density and penetrometer resistance of a sandy clay loam soil. South African Journal of Plant and Soil 12(2):86-90.

Taylor, H.M. and Brar, G.S. 1991. Effect of soil compaction on root development. Soil \&Tillage Research19:111-119.

Taylor, H.M. and Ratliff, L.F. 1969. Root elongation rates of cotton and peanuts as a function of soil strength and soil water content. Soil Science 108:113-119.

Taylor, H.M., Upchurch, D.R., Brown, J.M. and Rogers, H.H.1991. Some methods of root investigations. In: Plant roots and their environment. McMichael, B.L. and Persson, H. (Eds.). Developments in agricultural and managed-forest ecology 24. Proceedings from an ISRR-symposium, August $21^{\text {st }}-26^{\text {th }}$ (1988, Uppsala, Sweden. Elsevier Science Publishing 
Company Inc., Amsterdam, Netherlands. pp. 553-564.

Tiller, D.B. 1975. The Sandveldt soils of Central Province, soil survey report No. 32. Soil Survey Section, Mount Makulu Research Station, Chilanga, Zambia.

Umar, B.B. 2012. Reversing agro-based land degradation through conservation agriculture: Emerging experiences from Zambia's smallholder farming sector. Sustainable Agriculture Research 1(2):72-87.

UNZA. 1998. Practical manual for fundamentals of soil science, $3^{\text {rd }}$ ed (2014/2015 update). Soil Science Department, School of Agricultural Sciences, University of Zambia, PO Box 32379, Lusaka, Zambia.

Usman, H. 1994. Cattle trampling and soil compaction effects on soil properties of a northeastern Nigerian sandy loam. Arid Soil Research and Rehabilitation 8(1):69-75.

Vaz, C.M.P., Manieri, J.M., de Maria, I.C. and Tuller, M. 2011. Modeling and correction of soil penetrometer resistance for varying soil water content. Geoderma 166:92-101.
Vázquez, M.D., Poschenrieder, C., Corrales, I. and Barceló, J. 1999. Changes in apoplastic aluminum during the initial growth response to aluminum by roots of a tolerant maize variety. Plant Physiology 119:435-444.

Wall, P.C., Thierfelder, C., Ngwira, A., Govaerts, B., Nyagumbo, I. and Baudron, F. 2014. Conservation agriculture in eastern and southern Africa. In: Conservation agriculture: Global prospects and challenges. Kanwar, R.A., Sahrawat, L. and Kassam, A.H. (Eds.). CABI, Oxfordshire, UK, pp. 263-292.

Wang, Z.R., Rui, Y.K., Shen, J.B. and Zhang, F.S. 2008. Effects of $\mathrm{N}$ fertilizer on root growth in Zea mays L. seedlings. Spanish Journal of Agricultural Research 6(4):677-682.

Weaver, J.E. 1925. Investigations on the root habits of plants. American Journal of Botany 12(8):502-509.

Whiteley, G.M., Utomo, W.H. and Dexter, A.R. 1981. A comparison of penetrometer pressures and the pressures exerted by roots. Plant and Soil 61:351-364. 